\title{
Middle Cambrian granites in the Dunhuang Block NW China mark the southernmost subduction in the Central Asian Orogen
}

Bao-Ping Gan ${ }^{1 *}$, Zheng-Xiang $\mathrm{Li}^{2}$, Zhi-Cheng Song ${ }^{3}$, Jiang-Yu Li ${ }^{2}$

${ }_{1}^{1}$ State Key Laboratory of Continental Dynamics, Department of Geology, Northwest University, Xi'an 710069, China

${ }^{2}$ Earth Dynamic Research Group, the Institute for Geoscience Research (TIGeR), Department of Applied Geology, Curtin University, Perth, WA 6845, Australia

${ }^{3}$ Northwest Geological Exploration Institute of China Metallurgical Geology Bureau, Xi'an 710119, China

The formation and evolution of the Central Asian Orogenic Belt (CAOB) are closely associated with the opening and closure of Paleo-Asian Ocean (PAO). The subduction processes of the southern PAO resulted in widespread Paleozoic subduction-related magmatic events in the southern CAOB. However, precise subduction location and timing remain debated, arguing the Dunhuang Block (DHB), which situated in the southernmost of the CAOB, may preserve the final subduction record. The Cambrian granites in the DHB mainly consist of Lianghu, Dapokouzi and Xiaowan plutons from the northeastern DHB, NW China, which were emplaced ca. 510Ma (Middle Cambrian). Geochemically, the Dapokouzi plutons has high $\mathrm{SiO}_{2}, \mathrm{Na}_{2} \mathrm{O}$, $\mathrm{Al}_{2} \mathrm{O}_{3}$, low $\mathrm{MgO}$ and $\mathrm{K}_{2} \mathrm{O}$ contents, medium $\mathrm{Mg}^{\#}$, as well as high $\mathrm{Sr}, \mathrm{Sr} / \mathrm{Y}$ ratios, low $\mathrm{Y}$ concentrations and weak positive $\mathrm{Eu}$ anomalies indicate the rocks to be of adakitic affinities. Positive $\varepsilon \mathrm{Hf}(t)$ values further indicate that they were derived from partial melting of thickened juvenile lower crust with addition of minor mantle-derived materials under highpressure conditions. Similarly, the Lianghu and Xiaowan plutons also have high $\mathrm{SiO}_{2}, \mathrm{Al}_{2} \mathrm{O}_{3}$, low $\mathrm{MgO}$ and $\mathrm{K}_{2} \mathrm{O}$ contents, low $\mathrm{Mg}^{\#}$ values. However, they exhibit low $\mathrm{Sr}, \mathrm{Y}$, $\mathrm{Sr} / \mathrm{Y}$ ratios and $\mathrm{Cr}-\mathrm{Co}-\mathrm{Ni}$ concentrations but high positive $\varepsilon_{\mathrm{Hf}}(t)$ values, indicating that they were produced from partial melting of juvenile lower crust at relatively shallow crustal depth and low-pressure conditions. Synthesized data from this and previous studies suggest that the DHB was located at a continental margin arc setting during Paleozoic, likely due to the southward subduction of the PAO lithosphere. Additionally, crustal thickening record as revealed from the geochemical signature of Dapokouzi pluton was most likely associated with lithospheric contraction by the underplating of mantle-derived mafic magmas during the slab subduction, which initiated prior to $510 \mathrm{Ma}$. 